\title{
The Changing Face of Financial Development"
}

\author{
by
}

\section{Panicos O. Demetriades ${ }^{a}$ and Peter L. Rousseau ${ }^{b}$}

\begin{abstract}
We provide evidence from a large number of countries which demonstrates the changing nature of the finance-growth nexus. Specifically, we show that financial depth is no longer a significant determinant of long-run growth. Instead we find evidence to suggest that certain financial reforms have sizeable growth effects, which can be positive or negative depending on how well banks are regulated and supervised.
\end{abstract}

\section{Revised December 2015}

\footnotetext{
* We acknowledge the support of ESRC-DFID grant number ES/J009067/1, and useful comments from workshop participants at the University of Glasgow and Brunel University. We would also like to thank an anonymous reviewer of this journal for constructive comments.

${ }^{\mathrm{a}}$ University of Leicester.

${ }^{\mathrm{b}}$ Vanderbilt University.
} 


\section{Introduction}

Recent research suggests that the impact of finance on growth is, at best, weakening (Rousseau and Wachtel, 2011) and, at worst, turning negative once financial development exceeds a certain threshold (Arcand et al., 2011). ${ }^{1}$ This paper confirms that the financegrowth nexus is indeed changing using a rich database on financial reforms covering 91 countries over 1973-2004 (Abiad et al., 2008). Specifically, we show that financial depth is no longer a significant determinant of long-run growth. Instead we find evidence to suggest that certain financial reforms have sizeable growth effects, which can be positive or negative depending on how well banks are regulated and supervised. Our findings warn against the use of composite measures of financial liberalisation; in fact, we show that a composite index of financial liberalisation has no independent effect on growth.

\section{Data and Methods}

Our study includes data on financial and macroeconomic aggregates from the 2009 edition of the World Development Indicators database for 84 countries for the period 19752004, combined with indicators of financial liberalization from Abiad et al. (2008). ${ }^{2}$ Our measure of financial depth is liquid liabilities less narrow money (M3 less M1), which removes the pure transactions component from liquid liabilities to isolate the intensity of

\footnotetext{
${ }^{1}$ Earlier concerns about the finance-growth relationship include the direction of causality (e.g., Demetriades and Hussein, 1996) and its variability across income groups (e.g., Rioja and Valev, 2004).

2 The 84 countries are Algeria, Argentina, Australia, Austria, Bangladesh, Barbados, Belgium, Bolivia, Brazil, Cameroon, Canada, Central African Republic, Chile, Colombia, Costa Rica, Cote d'Ivoire, Denmark, Dominican Republic, Ecuador, Egypt, El Salvador, Fiji, Finland, France, Gambia, Ghana, Greece, Guatemala, Guyana, Haiti, Honduras, Iceland, India, Indonesia, Iran, Ireland, Israel, Italy, Jamaica, Japan, Jordan, Kenya, Republic of Korea, Lesotho, Luxembourg, Malawi, Malaysia, Malta, Mauritius, Mexico, Morocco, Nepal, Netherlands, New Zealand, Nicaragua, Niger, Nigeria, Norway, Pakistan, Panama, Papua New Guinea, Paraguay, Peru, Philippines, Portugal, Rwanda, Senegal, Sierra Leone, South Africa, Spain, Sri Lanka, Sudan, Sweden, Switzerland, Syrian Arab Republic, Thailand, Trinidad and Tobago, Togo, Turkey, United Kingdom, United States, Uruguay, Venezuela, and Zimbabwe.
} 
financial intermediation. ${ }^{3}$

The main analysis consists of a series of cross-sectional regressions in the style of King and Levine (1993) that take the form

$$
\mathrm{Y}_{\mathrm{it}}=\alpha_{0}+\alpha \mathrm{F}_{\mathrm{it}}+\beta \mathrm{FL}_{\mathrm{it}}+\gamma \mathrm{X}_{\mathrm{it}}+\mathrm{u}_{\mathrm{it}}
$$

where $\mathrm{Y}_{\mathrm{it}}$ is the growth of real per capita GDP in country $i$ at time $t, \mathrm{~F}_{\mathrm{it}}$ is a measure of financial depth, $\mathrm{FL}_{\mathrm{it}}$ is an indicator of financial liberalization or reform, and $\mathrm{X}_{\mathrm{it}}$ is a set of explanatory variables that have been shown to be robust determinants of growth. The $\mathrm{X}$ variables include the log of initial real per capita GDP, which captures convergence, the log of the initial secondary school enrollment rate, which reflects investment in human capital, and the ratios of trade (i.e., imports plus exports) and government expenditure to GDP.

We utilize an overall composite index of financial liberalization, which is the sum of seven individual reform components measured on a scale ranging from 0-3 where 3 represents the highest degree of liberalisation. The seven components are the strength of banking supervision, the ease of bank entry, the absence of distortions in credit allocation including the absence of high reserve requirements (ease of credit controls), the sophistication of securities markets, and the extent of privatisation, interest rate liberalisation and capital account openness.

The dependent variable is the average annual growth rate over five-year periods. To reduce simultaneity bias we use initial values from the start of each five-year period for all explanatory variables. All panel estimates include time fixed effects.

\footnotetext{
${ }^{3}$ Credit allocated to the private sector is a common alternative measure of financial development used in the literature on finance and growth. We prefer M3-M1 because it is more consistently measured across countries and over time, and this is critical for interpreting the cross-sectional and time variation in the data that drive the comparisons we make. When we use private credit in place of M3-M1 in our empirical specifications, the results are qualitatively identical.
} 


\section{Empirical Results}

Table 1 examines the effects of the composite financial liberalisation index on growth for the full 1975-2004 sample and two sub-periods, 1975-89 and 1990-2004. The first column for each of the three periods represents the standard baseline regression of the finance-growth nexus and, as such, does not include the liberalisation measure. These columns are similar to Rousseau and Wachtel (2011), with initial financial depth positively related to subsequent growth in the overall period, which decomposes into a strong and highly significant effect in the first sub-period and an insignificant effect in the second. The remaining columns include the liberalisation index in each of the same three periods. The index enters with a positive coefficient in all three periods, but is statistically insignificant throughout. Thus, the finance-growth nexus in the 1990-2004 period cannot be recovered by introducing the composite liberalisation index. This is, in some sense, not surprising. Rousseau and Wachtel (2011) show that the finance-growth nexus remains intact for countries able to avoid financial crises. Indeed, there is considerable evidence suggesting that financial liberalisation is often followed by crises, particularly when financial regulation and supervision are not strengthened at the same time. This dates back to the 'sequencing' literature, which emphasises that banking supervision is critical to the success of financial liberalisation (McKinnon, 1991; Villanueva and Mirakhor, 1990).

Interestingly, the composite index of financial liberalisation includes 'banking supervision' as one of its components. This encompasses aspects of both supervision and regulation, including the independence of bank supervisors, the effectiveness of supervision and the adoption of Basel capital standards. Thus in some sense the composite index is more a broad index of financial reforms than a pure liberalisation index. It is, therefore, potentially more promising to explore whether the individual components, including banking 
supervision, can help to recover the influence of financial development on growth in the 1990-2004 period.

To this end, Table 2 introduces the individual components of the index into the baseline regression. The first column includes all the components, although it must be recognised that this specification may be susceptible to problems of multicollinearity since the individual components are correlated. ${ }^{4}$ We reverse the banking supervision component to capture weakness, which helps to make our point more clearly (thus, weakness of banking supervision takes the value 0 when banking supervision is at its best and +3 when it is at its worst). This model indeed confirms that banking supervision may indeed be a 'supervariable' - it is highly significant and has the expected sign. Moreover, the financial depth variable remains insignificant throughout. Two of the other components are significant at the 5\% level: ease of credit controls, which enters with a positive sign, and extent of privatisation, with a negative sign. Given the potential for multicollinearity, we also enter each of the components of the index separately. Weakness of banking supervision, which is included on its own in column 2 , is now significant at the $1 \%$ level and continues to have the expected negative sign. Ease of credit controls remains positive and highly significant, and extent of privatisation continues to have a negative sign but is now significant at only the $10 \%$ level. $^{5}$

Table 3 provides more direct evidence on our main hypothesis by interacting weakness of banking supervision with each of the other components of the index, which also enters linearly in each regression. We are thus able to examine whether the effects of

\footnotetext{
${ }^{4}$ The correlation coefficients between the individual components entered in this model range (in absolute values) from 0.316 to 0.639 .

${ }^{5}$ In an earlier version of this paper, we carried out a similar analysis to what is presented in Table 2 for 1975-89. This showed that all reforms measures were statistically insignificant other than securities markets. In the case of banking supervision, however, its insignificance in the earlier period reflects low values and a general lack of identifying variation.
} 
individual reforms depend on the regulatory and supervisory framework. Columns 1-6 present the relevant results. All the interaction terms are negative and statistically significant, often at the $1 \%$ level. Moreover, the effect of financial depth remains negligible and insignificant. These findings confirm clearly that our main conjecture is valid: pro-market financial reforms can have negative effects on growth in economies with weak regulation and supervision. The reform variables themselves are positive but are statistically significant only in two cases: ease of credit controls and securities markets. Taken at face value, these results suggest that these two types of reforms may help to increase growth if the regulatory and supervisory framework is not too weak. Given the potential for multicollinearity between various reform measures, however, we hesitate to conclude which of the reform measures work better from these results alone. To shed further light on the most likely 'winners', column 7 in Table 3 presents our preferred specification obtained from a general to specific model search. It shows that easing credit controls by one index unit in a well regulated environment can raise conditional growth rates by one percentage point per year. A computation of marginal effects of credit controls at weaker levels of supervision reveals that they remain positive and statistically significant except at the weakest level. It also shows that other reforms may have negative effects. Specifically, a one unit increase in the bank privatisation component relates to growth rates that are lower by $0.4 \%$, a result consistent with recent evidence on government ownership of banks in cross-country growth regressions by Andrianova et al. (2012).

\section{Summary and concluding remarks}

We provide new evidence which confirms that the finance-growth relationship has been changing. While from 1975-1989 more finance seems to have resulted in more growth, the same is not true for 1990-2004. During the latter period, banking regulation and 
supervision is found to play a much more important role than financial depth, indicating that what matters for growth now is how well the financial system is regulated. Our findings, for example, suggest that liberalising credit allocation can result in substantially higher long-run growth in well regulated and supervised banking systems, but this effect declines with the quality of regulation and supervision. Some of the evidence we present even suggests that other reform measures may have negative effects on growth, unless the banking system is well regulated and supervised. Our findings are therefore consistent with recent literature that links financial reforms to banking crises (e.g., Ang, 2011), although they also shed new light on the types of reforms that can help avoid banking crises. Finally, they highlight the need for more research on the interactions between financial reforms, financial fragility and growth. ${ }^{6}$

\section{References}

Abiad, A., E. Detragiache and T. Tressel (2008). "A New Database of Financial Reforms." IMF Working Paper 08/266.

Andrianova, S., P. Demetriades and A. Shortland (2012). "Government Ownership of Banks, Institutions and Economic Growth.” Economica 79, 449-469.

Ang, J. B. (2011). “Financial Development, Liberalization and Technological Deepening.” European Economic Review 55, 688-701.

Arcand, J. L., E. Berkes and U. Panizza (2011). “Too Much Finance?”, VOX-EU, April. Demetriades, P. O., and K. A. Hussein (1996). "Does Financial Development Cause Economic Growth? Time-series Evidence from 16 Countries.” Journal of Development Economics 51, 387-411.

\footnotetext{
${ }^{6}$ A potentially fruitful avenue for further research is to examine whether financial development still matters in countries with better supervised banking systems. Such a question can be better addressed using time series data and methods.
} 
King, R. G., and R. Levine (1993). "Finance and Growth: Schumpeter Might be Right." Quarterly Journal of Economics 108, 717-737.

McKinnon, R. I. (1991). The Order of Economic Liberalisation: Financial Control in the Transition to a Market Economy. Baltimore: Johns Hopkins University Press.

Rioja, F. and N. Valev (2004). "Does One Size Fit All?: A Re-examination of the Finance and Growth Relationship.” Journal of Development Economics 74, 429-447.

Rousseau, P. L. and P. Wachtel (2011). "What is Happening to the Impact of Financial Deepening on Economic Growth?” Economic Inquiry 49, 276-288.

Villanueva, D. and A. Mirakhor (1990). "Strategies for Financial Reforms: Interest Rate Policies, Stabilisation, and Bank Supervision in Developing Countries." IMF Staff Papers 37, 509-536. 
TABLE 1

FINANCIAL DEPTH, FINANCIAL LIBERALISATION AND GROWTH

IN A PANEL OF COUNTRIES

OLS Regressions with 5-Year Panel Data

\begin{tabular}{|c|c|c|c|c|c|c|}
\hline \multirow{2}{*}{$\begin{array}{l}\text { Regressors } \\
\text { Liquid liabilities less M1 } \\
(\% \text { of GDP) }\end{array}$} & \multicolumn{2}{|c|}{$1975-2004$} & \multicolumn{2}{|c|}{ 1975-1989 } & \multicolumn{2}{|c|}{$1990-2004$} \\
\hline & $\begin{array}{l}0.018^{* *} \\
(0.008)\end{array}$ & $\begin{array}{l}0.017^{* *} \\
(0.008)\end{array}$ & $\begin{array}{l}0.041^{* * *} \\
(0.015)\end{array}$ & $\begin{array}{l}0.040^{* *} \\
(0.015)\end{array}$ & $\begin{array}{c}0.005 \\
(0.008)\end{array}$ & $\begin{array}{c}0.005 \\
(0.008)\end{array}$ \\
\hline Financial liberalisation & --- & $\begin{array}{c}0.489 \\
(0.874)\end{array}$ & --- & $\begin{array}{r}0.902 \\
(1.352)\end{array}$ & --- & $\begin{array}{c}0.043 \\
(1.101)\end{array}$ \\
\hline $\begin{array}{l}\text { Trade openness } \\
(\% \text { of GDP })\end{array}$ & $\begin{array}{l}0.009^{*} \\
(0.005)\end{array}$ & $\begin{array}{c}0.008^{*} \\
(0.005)\end{array}$ & $\begin{array}{c}0.008 \\
(0.009)\end{array}$ & $\begin{array}{c}0.007 \\
(0.009)\end{array}$ & $\begin{array}{l}0.010^{* *} \\
(0.005)\end{array}$ & $\begin{array}{l}0.010^{*} \\
(0.005)\end{array}$ \\
\hline $\begin{array}{l}\text { Government expenditure } \\
(\% \text { of GDP) }\end{array}$ & $\begin{array}{c}-0.080^{* * *} \\
(0.025)\end{array}$ & $\begin{array}{c}-0.080^{* * *} \\
(0.025)\end{array}$ & $\begin{array}{l}-0.049 \\
(0.041)\end{array}$ & $\begin{array}{l}-0.048 \\
(0.041)\end{array}$ & $\begin{array}{l}-0.121^{* * *} \\
(0.030)\end{array}$ & $\begin{array}{c}-0.122^{* * *} \\
(0.030)\end{array}$ \\
\hline $\begin{array}{l}\text { Real GDP per capita } \\
\text { (in } 2000 \text { US\$) }\end{array}$ & $\begin{array}{l}-0.250^{*} \\
(0.150)\end{array}$ & $\begin{array}{l}-0.295^{*} \\
(0.171)\end{array}$ & $\begin{array}{l}-0.477^{*} \\
(0.348)\end{array}$ & $\begin{array}{l}-0.556^{* *} \\
(0.275)\end{array}$ & $\begin{array}{l}-0.126 \\
(0.181)\end{array}$ & $\begin{array}{l}-0.130 \\
(0.206)\end{array}$ \\
\hline $\begin{array}{l}\text { Secondary school } \\
\text { enrolment rate }\end{array}$ & $\begin{array}{l}1.259^{* * *} \\
(0.362)\end{array}$ & $\begin{array}{l}1.261^{* * *} \\
(0.362)\end{array}$ & $\begin{array}{l}1.184^{* * *} \\
(0.510)\end{array}$ & $\begin{array}{l}1.202^{* *} \\
(0.512)\end{array}$ & $\begin{array}{l}1.406^{* * *} \\
(0.520)\end{array}$ & $\begin{array}{l}1.405^{* * *} \\
(0.523)\end{array}$ \\
\hline $\mathrm{R}^{2}$ & 0.149 & 0.150 & 0.170 & 0.172 & 0.156 & 0.156 \\
\hline No. of observations & 333 & 333 & 170 & 170 & 163 & 163 \\
\hline
\end{tabular}

Notes: Regressors are initial values from each respective five-year period. All regressions include dummy variables for the five-year time periods. ${ }^{*},{ }^{* *}$ and ${ }^{* * *}$ denote statistical significance at the $10 \%$, $5 \%$ and $1 \%$ levels, respectively, with standard errors in parentheses. 
TABLE 2

FINANCIAL DEPTH, FINANCIAL REFORMS AND GROWTH

IN A PANEL OF COUNTRIES 1990-2004

OLS Regressions with 5-Year Panel Data

\begin{tabular}{|c|c|c|c|c|c|c|c|c|}
\hline Regressors & (1) & (2) & (3) & (4) & $(5)$ & (6) & (7) & (8) \\
\hline $\begin{array}{l}\text { Liquid liabilities less M1 } \\
\text { (\% of GDP) }\end{array}$ & $\begin{array}{c}0.004 \\
(0.008)\end{array}$ & $\begin{array}{c}0.005 \\
(0.008)\end{array}$ & $\begin{array}{c}0.005 \\
(0.008)\end{array}$ & $\begin{array}{c}0.005 \\
(0.008)\end{array}$ & $\begin{array}{c}0.004 \\
(0.008)\end{array}$ & $\begin{array}{c}0.005 \\
(0.008)\end{array}$ & $\begin{array}{c}0.005 \\
(0.008)\end{array}$ & $\begin{array}{c}0.006 \\
(0.008)\end{array}$ \\
\hline $\begin{array}{l}\text { Weakness of bank } \\
\text { supervision }\end{array}$ & $\begin{array}{l}-0.693^{* *} \\
(0.268)\end{array}$ & $\begin{array}{l}-0.669^{* * *} \\
(0.257)\end{array}$ & & & & & & \\
\hline Ease of credit controls & $\begin{array}{l}0.442^{* *} \\
(0.180)\end{array}$ & --- & $\begin{array}{l}0.408^{* *} \\
(0.178)\end{array}$ & --- & --- & --- & --- & --- \\
\hline Extent of privatisation & $\begin{array}{l}-0.346^{* *} \\
(0.152)\end{array}$ & --- & --- & $\begin{array}{l}-0.240^{*} \\
(0.148)\end{array}$ & --- & --- & --- & --- \\
\hline Securities markets & $\begin{array}{c}0.071 \\
(0.245)\end{array}$ & --- & --- & --- & $\begin{array}{c}0.155 \\
(0.228)\end{array}$ & --- & --- & --- \\
\hline Ease of bank entry & $\begin{array}{l}-0.236 \\
(0.180)\end{array}$ & --- & --- & --- & --- & $\begin{array}{l}-0.230 \\
(0.180)\end{array}$ & --- & --- \\
\hline Interest rate liberalisation & $\begin{array}{l}-0.103 \\
(0.212)\end{array}$ & --- & --- & --- & --- & --- & $\begin{array}{l}-0.189 \\
(0.203)\end{array}$ & --- \\
\hline Capital account openness & $\begin{array}{c}0.091 \\
(0.224)\end{array}$ & --- & --- & --- & --- & --- & --- & $\begin{array}{l}-0.084 \\
(0.202)\end{array}$ \\
\hline $\begin{array}{l}\text { Trade openness } \\
(\% \text { of GDP) }\end{array}$ & $\begin{array}{l}0.012^{* *} \\
(0.005)\end{array}$ & $\begin{array}{l}0.009^{*} \\
(0.005)\end{array}$ & $\begin{array}{l}0.009^{*} \\
(0.005)\end{array}$ & $\begin{array}{l}0.011^{* *} \\
(0.005)\end{array}$ & $\begin{array}{l}0.010^{* *} \\
(0.005)\end{array}$ & $\begin{array}{l}0.011^{* *} \\
(0.005)\end{array}$ & $\begin{array}{l}0.010^{* *} \\
(0.005)\end{array}$ & $\begin{array}{l}0.010^{* *} \\
(0.005)\end{array}$ \\
\hline $\begin{array}{l}\text { Government expenditure } \\
(\% \text { of GDP) }\end{array}$ & $\begin{array}{c}-0.131^{* * *} \\
(0.030)\end{array}$ & $\begin{array}{c}-0.137^{* * *} \\
(0.030)\end{array}$ & $\begin{array}{c}-0.119^{* * *} \\
(0.030)\end{array}$ & $\begin{array}{c}-0.119^{* * *} \\
(0.030)\end{array}$ & $\begin{array}{c}-0.123^{* * *} \\
(0.030)\end{array}$ & $\begin{array}{c}-0.121^{* * *} \\
(0.030)\end{array}$ & $\begin{array}{c}-0.123^{* * *} \\
(0.030)\end{array}$ & $\begin{array}{c}-0.121^{* * *} \\
(0.030)\end{array}$ \\
\hline $\begin{array}{l}\text { Real GDP per capita } \\
\text { (in } 2000 \text { US\$) }\end{array}$ & $\begin{array}{l}-0.258 \\
(0.204)\end{array}$ & $\begin{array}{l}-0.328^{*} \\
(0.194)\end{array}$ & $\begin{array}{l}-0.238 \\
(0.185)\end{array}$ & $\begin{array}{l}-0.039 \\
(0.188)\end{array}$ & $\begin{array}{l}-0.166 \\
(0.190)\end{array}$ & $\begin{array}{l}-0.083 \\
(0.184)\end{array}$ & $\begin{array}{l}-0.103 \\
(0.183)\end{array}$ & $\begin{array}{l}-0.095 \\
(0.196)\end{array}$ \\
\hline $\begin{array}{l}\text { Secondary school } \\
\text { enrolment rate }\end{array}$ & $\begin{array}{l}1.121^{* *} \\
(0.529)\end{array}$ & $\begin{array}{l}1.268^{* *} \\
(0.514)\end{array}$ & $\begin{array}{l}1.381^{* * *} \\
(0.514)\end{array}$ & $\begin{array}{l}1.291^{* *} \\
(0.523)\end{array}$ & $\begin{array}{l}1.354^{* *} \\
(0.527)\end{array}$ & $\begin{array}{l}1.440^{* * *} \\
(0.520)\end{array}$ & $\begin{array}{l}1.492^{* * *} \\
(0.529)\end{array}$ & $\begin{array}{l}1.400^{* * *} \\
(0.522)\end{array}$ \\
\hline $\mathrm{R}^{2}$ & 0.257 & 0.192 & 0.184 & 0.170 & 0.159 & 0.165 & 0.161 & 0.161 \\
\hline No. of observations & 163 & 163 & 163 & 163 & 163 & 163 & 163 & 163 \\
\hline
\end{tabular}

Notes: Regressors are initial values from each respective five-year period. All regressions include dummy variables for the five-year time periods. ${ }^{*},{ }^{* *}$ and ${ }^{* * *}$ denote statistical significance at the $10 \%, 5 \%$ and $1 \%$ levels, respectively, with standard errors in parentheses. 
TABLE 3

FINANCIAL DEPTH, FINANCIAL REFORMS AND GROWTH

IN A PANEL OF COUNTRIES WITH BANK SUPERVISION INTERACTIONS, 1990-2004

OLS Regressions with 5-Year Panel Data

\begin{tabular}{|c|c|c|c|c|c|c|c|}
\hline Regressors & $(1)$ & $(2)$ & (3) & (4) & $(5)$ & $(6)$ & $(7)$ \\
\hline $\begin{array}{l}\text { Liquid liabilities less M1 } \\
\text { (\% of GDP) }\end{array}$ & $\begin{array}{c}0.005 \\
(0.008)\end{array}$ & $\begin{array}{c}0.006 \\
(0.008)\end{array}$ & $\begin{array}{c}0.006 \\
(0.008)\end{array}$ & $\begin{array}{c}0.005 \\
(0.008)\end{array}$ & $\begin{array}{c}0.005 \\
(0.008)\end{array}$ & $\begin{array}{c}0.007 \\
(0.008)\end{array}$ & $\begin{array}{c}0.005 \\
(0.008)\end{array}$ \\
\hline Ease of credit controls & $\begin{array}{l}0.830^{* * *} \\
(0.267)\end{array}$ & --- & --- & --- & --- & --- & $\begin{array}{l}1.032^{* * *} \\
(0.273)\end{array}$ \\
\hline Extent of privatisation & --- & $\begin{array}{c}0.230 \\
(0.229)\end{array}$ & --- & --- & --- & --- & $\begin{array}{l}-0.395^{* * *} \\
(0.295)\end{array}$ \\
\hline Securities markets & --- & --- & $\begin{array}{l}0.623^{* *} \\
(0.295)\end{array}$ & --- & --- & --- & --- \\
\hline Ease of bank entry & --- & --- & --- & $\begin{array}{c}0.383 \\
(0.285)\end{array}$ & --- & --- & --- \\
\hline Interest rate liberalisation & --- & --- & --- & --- & $\begin{array}{c}0.482 \\
(0.321)\end{array}$ & --- & --- \\
\hline Capital account openness & --- & --- & --- & --- & --- & $\begin{array}{c}0.458 \\
(0.287)\end{array}$ & --- \\
\hline $\begin{array}{l}\text { Index x weakness of bank } \\
\text { supervision }\end{array}$ & $\begin{array}{l}-0.199^{* *} \\
(0.095)\end{array}$ & $\begin{array}{l}-0.267^{* * *} \\
(0.100)\end{array}$ & $\begin{array}{l}-0.228^{* *} \\
(0.093)\end{array}$ & $\begin{array}{l}-0.253^{* * *} \\
(0.092)\end{array}$ & $\begin{array}{l}-0.234^{* * *} \\
(0.088)\end{array}$ & $\begin{array}{l}-0.232^{* * *} \\
(0.089)\end{array}$ & $\begin{array}{l}-0.255^{* *} \\
(0.096)\end{array}$ \\
\hline $\begin{array}{l}\text { Trade openness } \\
(\% \text { of GDP) }\end{array}$ & $\begin{array}{l}0.009^{*} \\
(0.005)\end{array}$ & $\begin{array}{l}0.012^{* *} \\
(0.005)\end{array}$ & $\begin{array}{l}0.009^{*} \\
(0.005)\end{array}$ & $\begin{array}{l}0.010^{* *} \\
(0.005)\end{array}$ & $\begin{array}{l}0.009^{*} \\
(0.005)\end{array}$ & $\begin{array}{l}0.009^{*} \\
(0.005)\end{array}$ & $\begin{array}{l}0.012^{* *} \\
(0.005)\end{array}$ \\
\hline $\begin{array}{l}\text { Government expenditure } \\
\text { (\% of GDP) }\end{array}$ & $\begin{array}{l}-0.131^{* * *} \\
(0.030)\end{array}$ & $\begin{array}{l}-0.129^{* * *} \\
(0.030)\end{array}$ & $\begin{array}{l}-0.137^{* * *} \\
(0.030)\end{array}$ & $\begin{array}{l}-0.134^{* * *} \\
(0.030)\end{array}$ & $\begin{array}{l}-0.140^{* * *} \\
(0.030)\end{array}$ & $\begin{array}{l}-0.139^{* * *} \\
(0.030)\end{array}$ & $\begin{array}{l}-0.129^{* * *} \\
(0.029)\end{array}$ \\
\hline $\begin{array}{l}\text { Real GDP per capita } \\
\text { (in } 2000 \text { US\$) }\end{array}$ & $\begin{array}{l}-0.374^{*} \\
(0.194)\end{array}$ & $\begin{array}{l}-0.135 \\
(0.188)\end{array}$ & $\begin{array}{l}-0.339^{*} \\
(0.200)\end{array}$ & $\begin{array}{l}-0.277 \\
(0.193)\end{array}$ & $\begin{array}{r}-0.298 \\
(0.194)\end{array}$ & $\begin{array}{l}-0.275 \\
(0.204)\end{array}$ & $\begin{array}{r}-0.292 \\
(0.193)\end{array}$ \\
\hline $\begin{array}{l}\text { Secondary school } \\
\text { enrolment rate }\end{array}$ & $\begin{array}{l}1.275^{* *} \\
(0.511)\end{array}$ & $\begin{array}{l}1.058^{* *} \\
(0.520)\end{array}$ & $\begin{array}{l}1.291^{* *} \\
(0.519)\end{array}$ & $\begin{array}{l}1.333^{* * *} \\
(0.511)\end{array}$ & $\begin{array}{l}1.306^{* *} \\
(0.523)\end{array}$ & $\begin{array}{l}1.283^{* *} \\
(0.515)\end{array}$ & $\begin{array}{l}1.050^{* *} \\
(0.508)\end{array}$ \\
\hline $\mathrm{R}^{2}$ & 0.207 & 0.207 & 0.190 & 0.204 & 0.198 & 0.193 & 0.242 \\
\hline No. of observations & 163 & 163 & 163 & 163 & 163 & 163 & 163 \\
\hline
\end{tabular}

Notes: Regressors are initial values from each respective five-year period. All regressions include dummy variables for the five-year time periods. ${ }^{*},{ }^{* *}$ and ${ }^{* * *}$ denote statistical significance at the $10 \%, 5 \%$, and $1 \%$ levels, respectively, with standard errors in parentheses. 